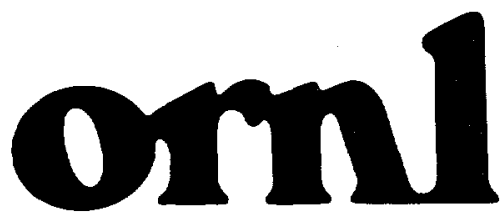

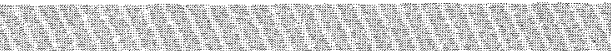

OAK RIDGE NATIONAL LABORATORY
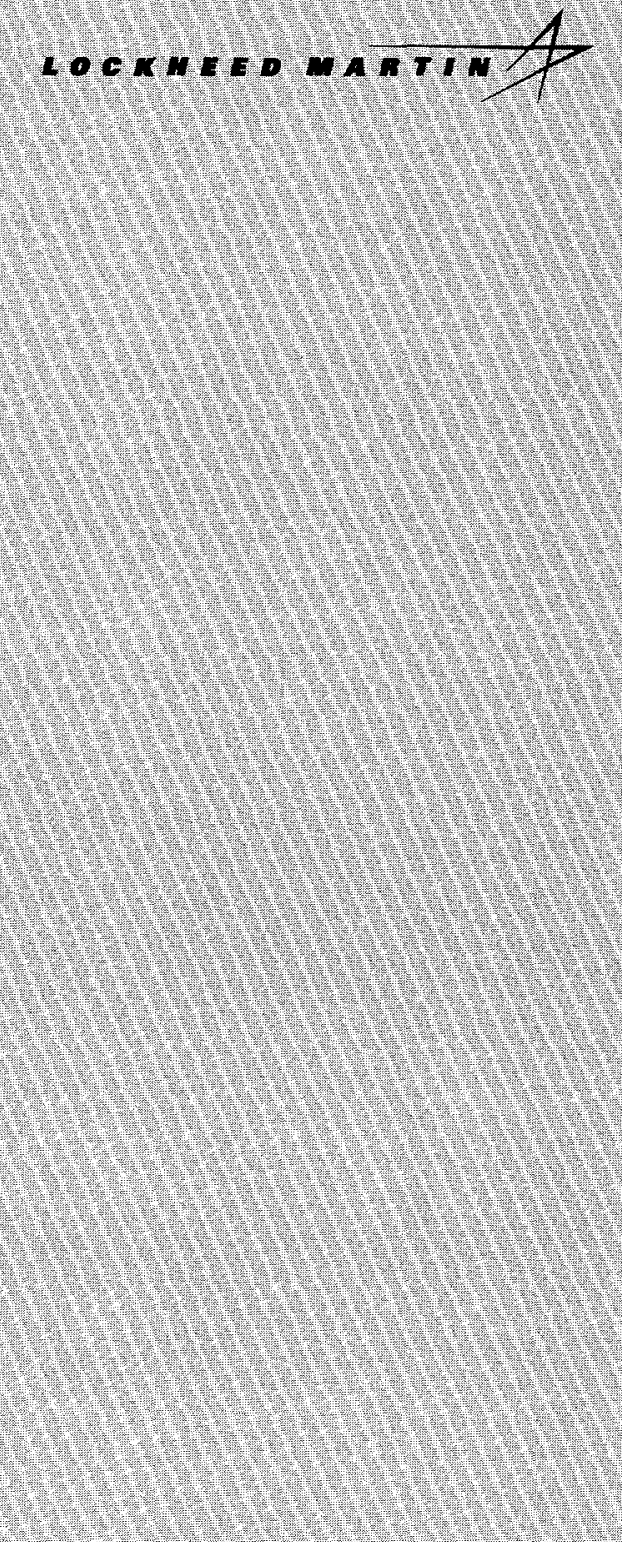

MANAGED AND OPERATED BY

LOCKHEED MARTIN ENERGY RESEARCH CORPORATION FORTHE UNTEO STATES

DEPARTUENT OF ENERGY

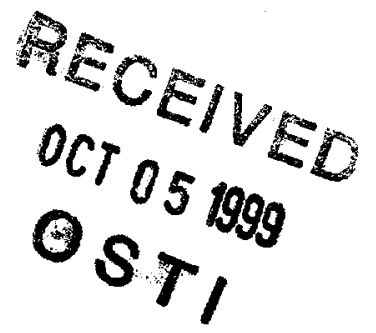

ORNL/TM-1999/108

\title{
San Onofre PWR Data for Code Validation of MOX Fuel Depletion Analyses
}

O. W. Hermann

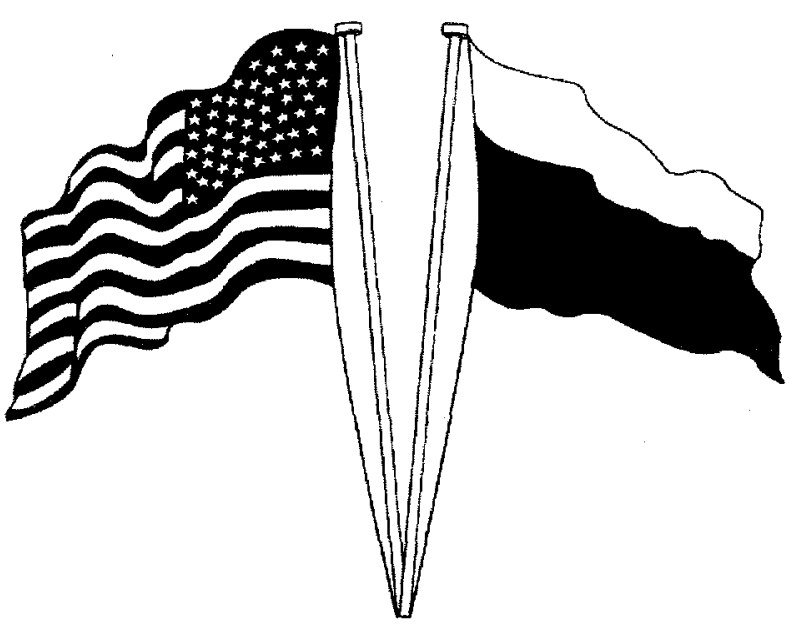

Fissile Materials Disposition Program 
This report has been reproduced directly from the best available copy.

Available to DOE and DOE contractors form the Office of Scientific and Technical Information, P.O. Box 62, Oak Ridge, TN 37831; prices available from (615) $576-8401$.

Available to the public from the National Technical Information Service U.S. Department of Commerce, 5285 Port Royal Rd., Springfield, VA 22161.

This report was prepared as an account of work sponsored by an agency of the United States Government. Neither the United States nor any agency thereof, nor any of their employees, makes any warranty, express or implied, or assumes any legal liability or responsibility for the accuracy, completeness, or usefulness of any information, apparatus, product, or process disclosed, or represents that its use would not infringe privately owned rights. Reference herein to any specific commercial product, process, or service by trade name, trademark, manufacturer, or otherwise, does not necessarily constitute or imply its endorsement, recommendation, or favoring by the United States Government or any agency thereof. The views and opinions of authors expressed herein do not necessarily state or reflect those of the United States Government or any agency thereof. 


\section{DISCLAIMER}

Portions of this document may be illegible in electronic image products. Images are produced from the best available original document. 
Computational Physics and Engineering Division

\title{
San Onofre PWR Data for Code Validation of MOX Fuel Depletion Analyses
}

O. W. Hermann

Date Published: September 1999

\author{
Prepared by the \\ OAK RIDGE NATIONAL LABORATORY \\ P.O. Box 2008 \\ Oak Ridge, Tennessee 37831-6370 \\ managed by \\ LOCKHEED MARTIN ENERGY RESEARCH CORP. \\ for the \\ U.S. DEPARTMENT OF ENERGY \\ under contract DE-AC05-96OR22464
}




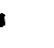




\section{CONTENTS}

Page

LIST OF FIGURES $\ldots \ldots \ldots \ldots \ldots \ldots \ldots \ldots \ldots \ldots \ldots \ldots \ldots \ldots \ldots \ldots$

LIST OF TABLES $\ldots \ldots \ldots \ldots \ldots \ldots \ldots \ldots \ldots \ldots \ldots \ldots \ldots \ldots \ldots \ldots \ldots$ vii

ACKNOWLEDGMENTS $\ldots \ldots \ldots \ldots \ldots \ldots \ldots \ldots \ldots \ldots \ldots \ldots \ldots \ldots \ldots \ldots \ldots$

ABSTRACT $\ldots \ldots \ldots \ldots \ldots \ldots \ldots \ldots \ldots \ldots \ldots \ldots \ldots \ldots \ldots \ldots \ldots \ldots \ldots \ldots \ldots \ldots$

1. INTRODUCTION $\ldots \ldots \ldots \ldots \ldots \ldots \ldots \ldots \ldots \ldots \ldots \ldots \ldots \ldots \ldots \ldots \ldots$

2. MOX FUEL ASSEMBLY DESIGN DATA $\ldots \ldots \ldots \ldots \ldots \ldots \ldots \ldots \ldots$

3. THE PWR OPERATIONS DATA AND MODEL OF ASSEMBLIES $\ldots \ldots \ldots \ldots \ldots$

4. ISOTOPIC MEASUREMENTS FOR MOX FUEL SAMPLES $\ldots \ldots \ldots \ldots \ldots \ldots$

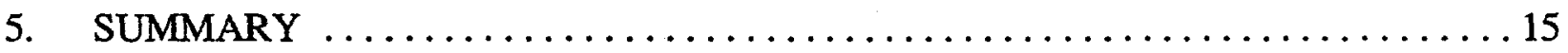

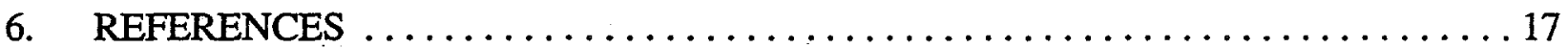

APPENDIX A - SAMPLE BURNUP DETERMINATIONS . . . . . . . . . . . 19

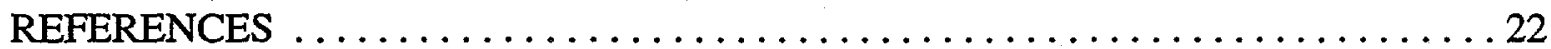





\section{LIST OF FIGURES}

Figure

Page

1. Location of rods removed from San Onofre Plutonium Demonstration Assembly D51X

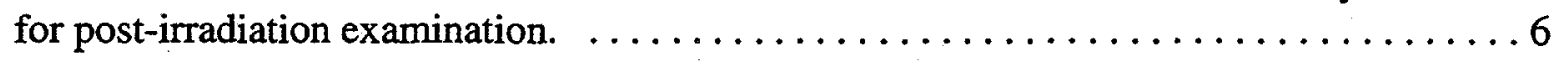

2. Enrichment pattern for the four plutonium assemblies. $\ldots \ldots \ldots \ldots \ldots \ldots \ldots \ldots$

3. Location of plutonium demonstration assemblies in San Onofre cycle 2 and cycle $3 \ldots \ldots 8$

4. Fuel temperature vs rod power for Obrigheim. Source: ref. $2 . \ldots \ldots \ldots \ldots \ldots \ldots 11$ 


\section{LIST OF TABLES}

Table

$\underline{\text { Page }}$

1. Basic parameters of measured MOX spent fuel samples $\ldots \ldots \ldots \ldots \ldots \ldots \ldots \ldots \ldots 2$

2. San Onofre MOX fuel assembly design data $\ldots \ldots \ldots \ldots \ldots \ldots \ldots \ldots \ldots \ldots$

3. Initial compositions of the uranium and plutonium $\ldots \ldots \ldots \ldots \ldots \ldots \ldots$

4. Fractional composition of $\mathrm{UO}_{2}$ and $\mathrm{PuO}_{2}$ in the $\mathrm{MOX}$ fuel $\ldots \ldots \ldots \ldots \ldots \ldots$

5. San Onofre operating data, including sample pellet powers and resonance-type

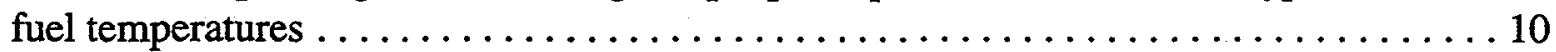

6. Effective SAS2H geometry of the San Onofre MOX assembly model $\ldots \ldots \ldots \ldots \ldots 12$

7. Measured isotopic compositions of San Onofre MOX spent fuel in atom ratios

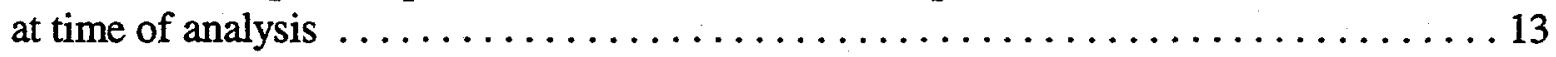

8. Measured isotopic compositions of San Onofre MOX spent fuel in atom ratios

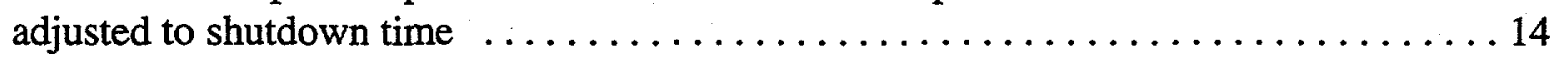

A.1 Data applied in determining recommended burnup $\ldots \ldots \ldots \ldots \ldots \ldots \ldots \ldots$

A.2 Calculation of burnup for each cycle for 2 -cycle cases $\ldots \ldots \ldots \ldots \ldots \ldots \ldots \ldots$ 


\section{ACKNOWLEDGMENTS}

The author wishes to thank Igor Carron, of Texas A\&M University, for his comprehensive literature search to produce all of the available reports containing data on the San Onofre MOX fuel demonstration program. Without his concern and productive results, this report could not have been produced.

The author is grateful to C. V. Parks for his guidance, and R. T. Primm M, M. D. DeHart, and B. D. Murphy for helpful advice on the project.

The work involved in this report was sponsored by the U.S. Department of Energy's Fissile Materials Disposition Program. 


\section{ABSTRACT}

The isotopic composition of mixed-oxide fuel (fabricated with both uranium and plutonium isotopes) discharged from reactors is of interest to the Fissile Material Disposition Program. The validation of depletion codes used to predict isotopic compositions of MOX fuel, similar to studies concerning uranium-only fueled reactors, thus, is very important. The EEI-Westinghouse Plutonium Recycle Demonstration Program was conducted to examine the use of MOX fuel in the San Onofre PWR, Unit I, during cycles 2 and 3. The data, usually required as input to depletion codes, either one-dimensional or lattice codes, were taken from various sources and compiled into this report. Where data were either lacking or determined inadequate, the appropriate data were supplied from other references. The scope of the reactor operations and design data, in addition to the isotopic analyses, was considered to be of sufficient quality for depletion code validation. 


\section{INTRODUCTION}

One goal of the U.S. Department of Energy's Fissile Materials Disposition Program ${ }^{1}$ (FMDP) is to certify the capability to predict the characteristics of mixed-oxide (MOX) spent fuel. Further, any fuel-depletion code for this purpose should be evaluated to determine how the accuracies of the computations compare with those of the more common low-enriched-uranium (LEU)-fueled lightwater reactors (LWRs). Validation studies have been performed for the SCALE code system fuel-depletion analyses of both pressurized-water reactors ${ }^{2,3}$ (PWRs) and boiling-water reactors ${ }^{4}$ (BWRs). During the operation of these reactors, the plutonium gradually increases in the fuel that initially contained uranium as the only actinide. However, there is a much more dominant influence on the flux and depletion characteristics from the plutonium in the MOX fuel because the plutonium concentration is several times greater than that of spent LEU fuel and it has a greater sensitivity to the thermal spectrum.

The EEI-Westinghouse Plutonium Recycle Demonstration Program, sponsored by Edison Electric Institute, Westinghouse Electric Corporation, and the Atomic Energy Commission, was conducted from 1968 to 1974. A significant part of this program involved the measurement of isotopic compositions of the uranium and plutonium in depleted MOX fuel withdrawn from the San Onofre PWR, a reactor having a Westinghouse design and operated by Southern California Edison and San Diego Gas \& Electric companies. The operating and design data typically required by fuel depletion codes can be found in a large number of sources. ${ }^{5-12}$ Also, the operating reports in the range from Docket 50206-79 through Docket 50206-201 contain similar data. The objective of this report is the compilation of the required data for fuel depletion codes into a single report. Data assumptions, which are considered to be reasonable, are included where the data are lacking. Even though input data for the SAS2H module of SCALE ${ }^{13}$ are the primary objectives of the compilation, an effort was made to include data required by lattice codes and other depletion codes.

Four MOX fuel assemblies were loaded at the start of cycle 2 of the San Onofre Nuclear Generation Station, Unit I and irradiated for both cycles 2 and 3. Then, isotopic composition analyses were conducted by the Westinghouse Electric Corporation on six sample pellets from four fuel rods of test assembly D51X. The basic parameters describing these six sample cases are listed in Table 1. Note that in all cases natural uranium was used, and three different weight percent values for fissile plutonium $\left({ }^{239} \mathrm{Pu}+{ }^{241} \mathrm{Pu}\right)$ were applied in the initial MOX fuel. Also, one may refer to the appendix of this report for details of the determination of the case burnups listed in Table 1. 
Table 1. Basic parameters of measured MOX spent fuel samples

\begin{tabular}{|c|c|c|c|c|c|c|c|}
\hline \multirow[b]{2}{*}{$\begin{array}{l}\text { Case } \\
\text { No. }\end{array}$} & \multirow[b]{2}{*}{$\begin{array}{l}\text { ID of test } \\
\text { assembly }\end{array}$} & \multirow[b]{2}{*}{$\begin{array}{c}\text { Pin } \\
\text { D }\end{array}$} & \multirow[b]{2}{*}{$\begin{array}{c}\text { Cycle } \\
\text { No. }\end{array}$} & \multicolumn{2}{|c|}{ Initial enrichment } & \multirow[b]{2}{*}{$\begin{array}{l}\text { Location } \\
\mathrm{ht}^{b} \text { (in.) }\end{array}$} & \multirow[b]{2}{*}{$\begin{array}{c}\text { Burnup }^{c} \\
(\mathrm{MWd} / \mathrm{MTHM})^{d}\end{array}$} \\
\hline & & & & $\begin{array}{c}\text { (atom \% } \\
\left.{ }^{235} U\right)^{a}\end{array}$ & (wt \% fissile $\mathrm{Pu}$ ) & & \\
\hline 1 & D51X & 067 & 2 & 0.72 & 3.31 & 53.0 & 8,167 \\
\hline 2 & D51X & 141 & 2 & 0.72 & 2.84 & 95.5 & 6,808 \\
\hline 3 & D51X & 079 & 2,3 & 0.72 & 3.10 & 49.0 & 20,891 \\
\hline 4 & D51X & 167 & 2,3 & 0.72 & 2.84 & 16.5 & 17,447 \\
\hline 5 & D51X & 167 & 2,3 & 0.72 & 2.84 & 95.5 & 18,713 \\
\hline 6 & D51X & 167 & 2,3 & 0.72 & 2.84 & 114.0 & 11,065 \\
\hline
\end{tabular}

${ }^{a}$ Taken from ref. 14.

${ }^{b}$ Height above bottom of active fuel.

Determination from ${ }^{148} \mathrm{Nd}$ measurements described in the appendix.

${ }^{d}$ Megawatt days per metric ton heavy metal $(\mathrm{U}+\mathrm{Pu})$.

Source: ref. 12, unless otherwise specified. 


\section{MOX FUEL ASSEMBLY DESIGN DATA}

The reactor fuel assembly design and fuel compositions for the four San Onofre MOX assemblies loaded in cycles 2 and 3 are presented in this section. The MOX fuel assembly design data, which would be significant to depletion codes, are listed in Table 2. Most of the data are taken from a Westinghouse report ${ }^{9}$ (WCAP-4167-2) that was issued near the start of the demonstration program. Some of the data presented in Table 2 were calculated, as noted, from other data in the table. The average soluble boron, not found in the available sources, was estimated to be $500 \mathrm{ppm}$ because the average for five PWRs in previous studies ${ }^{2,3}$ was $490 \mathrm{ppm}$. The guide tube dimensions were taken from data for the uranium-only assemblies. Although the tube sizes and boron content could have been different, the change would probably not have a significant influence on results.

The initial isotopic compositions of the uranium and plutonium in the MOX fuel of the San Onofre PWR are given in Table 3. Two deficiencies are noted in the initial plutonium data of this table. First, it is known that the plutonium is recycled plutonium from spent fuel and ${ }^{238} \mathrm{Pu} /{ }^{239} \mathrm{Pu}$ ratios are usually from 0.02 to 0.04 in typical PWR spent fuel. ${ }^{2,3}$ However, no ${ }^{238} \mathrm{Pu}$ is listed in the available data, and its absence needs to be considered in evaluating the uncertainty related to predicted analytic results. The other deficiency in the initial Pu specifications is that the decay of the 14.35-year half-life ${ }^{241} \mathrm{Pu}$ is not considered. In the fuel-assembly fabrication program, 17 analyses were made on ${ }^{239} \mathrm{Pu}$ and ${ }^{241} \mathrm{Pu}$ in revised analyses (as indicated in Table 3) for accountability. The change in ${ }^{241} \mathrm{Pu}$ composition, thus, can be taken into account.

The fractional composition of $\mathrm{UO}_{2}$ and $\mathrm{PuO}_{2}$ for the different values of wt $\%$ fissile plutonium are presented in Table 4. The weight fraction of $\mathrm{UO}_{2}$ and $\mathrm{PuO}_{2}$ in the $\mathrm{MOX}$ fuel is useful in determining fuel atomic densities or, more directly, as values input in the arbitrary material data of the fuel input to SAS2H. These weight fractions were calculated from the fuel stack density of Table 2, the initial isotopic atom compositions of Table 3 and the atomic weights ${ }^{14}$ of the $U$ and $\mathrm{Pu}$ isotopes. The initial Pu isotopic data were used because the revised data are incomplete. However, the decay time for the ${ }^{241} \mathrm{Pu}$ to change (5.2 to $4.8 \%$ ) was calculated to be 1.66 year, or 605 days. The depletion code input should have a 605-day step of decay (or very low power) that precedes the irradiation cycles, accounting for the ${ }^{241} \mathrm{Pu}$ change. Although the revised data are incomplete, code input may either be revised to $4.8 \%$ for ${ }^{241} \mathrm{Pu}$ or include the 605 -day step of decay.

The locations of the four fuel pins analyzed from the MOX fuel assembly D51X, listed in Table 1, are shown in Fig. 1. A complete description of the assembly, showing the fissile plutonium enrichment pattern, is presented in Fig. 2 . This information would probably be required for depletion lattice codes. The locations of the four MOX fuel assemblies during cycles 2 and 3, are shown in Fig. 3. Lattice depletion code input may use the fact that assembly D51X is adjacent to the reflector region in cycle 2 . 
Table 2. San Onofre MOX fuel assembly design data

\begin{tabular}{|c|c|}
\hline Parameter & Data \\
\hline \multicolumn{2}{|l|}{ Assembly general data } \\
\hline $\begin{array}{l}\text { Designer } \\
\text { Rod lattice } \\
\text { Number of assemblies/core }{ }^{a} \\
\text { MOX assemblies in cycles } 2 \text { and } 3 \\
\text { Total MOX loading, metric ton heavy metal, } \mathrm{MTHM}^{b} \\
\text { MOX fuel/assembly, } \mathrm{kg} \mathrm{U}+\mathrm{Pu}^{c} \\
\text { Number of MOX fuel rods } \\
\text { Number of instrument tubes } \\
\text { Number of guide tubes } \\
\text { Equivalent core diameter, } \mathrm{cm}(\mathrm{in} .)^{a} \\
\text { Assembly pitch, cm (in.) } \\
\mathrm{H}_{2} \mathrm{O} \text { moderator pressure, } \mathrm{psia}^{a} \\
\text { Average moderator temperature, } \mathrm{K}\left({ }^{\circ} \mathrm{F}\right)^{b} \\
\text { Average moderator density, } \mathrm{g} / \mathrm{cm}^{3} c \\
\text { Average clad temperature, } \mathrm{K}\left({ }^{\circ} \mathrm{F}\right)^{b} \\
\text { Soluble boron (estimated), } \mathrm{ppm}(\mathrm{wt})^{e}\end{array}$ & $\begin{array}{l}\text { Westinghouse Electric } \\
14 \times 14 \\
157 \\
4 \\
1.335 \\
333.75 \\
180 \\
1 \\
15 \\
282(111) \\
19.941(7.851) \\
2100 \\
576.5(578) \\
0.7179 \\
615(648) \\
500\end{array}$ \\
\hline \multicolumn{2}{|l|}{ Fuel rod data } \\
\hline $\begin{array}{l}\text { Type of fuel pellet } \\
\text { Stack density, } \mathrm{g} / \mathrm{cm}^{3} c \\
\text { Rod pitch, } \mathrm{cm} \text { (in.) } \\
\text { Clad OD, cm (in.) } \\
\text { Diametrical gap, } \mathrm{cm} \text { (in.) } \\
\text { Clad thickness, cm (in.) } \\
\text { Clad ID, cm (in.) } \\
\text { Pellet OD, cm (in.) } \\
\text { Active fuel length, cm (in.) } \\
\text { Clad material }\end{array}$ & $\begin{array}{l}\mathrm{UO}_{2} \text { plus } \mathrm{PuO}_{2} \text { (or MOX) } \\
10.2235 \\
1.41224(0.556) \\
1.07188(0.422) \\
0.01905(0.0075) \\
0.06172(0.0243) \\
0.94844(0.3734) \\
0.92939(0.3659) \\
303.28(119.4) \\
\text { Zircaloy-4 }\end{array}$ \\
\hline \multicolumn{2}{|l|}{ Guide tubes } \\
\hline $\begin{array}{l}\text { Material } \\
\text { Tube ID, cm (in. })^{f} \\
\text { Tube OD, cm (in. })^{f}\end{array}$ & $\begin{array}{l}\text { Stainless steel-304 } \\
1.29794(0.511) \\
1.35890(0.535)\end{array}$ \\
\hline
\end{tabular}

aTaken from ref. 6.

${ }^{b}$ Taken from ref. 5 .

${ }^{c}$ Calculated from other data in table.

${ }^{d}$ Taken from ref. 10 or 11.

${ }^{e}$ Assumed from similar reactors.

${ }^{f}$ Assumed similar to that of $U$ assemblies, taken from ref. 7 .

Source: ref. 9, unless otherwise specified. 
Table 3. Initial compositions of the uranium and plutonium

\begin{tabular}{|c|c|c|c|}
\hline Isotope & \multicolumn{3}{|c|}{ Atom $\%$ in $\mathrm{U}$ or $\mathrm{Pu}, \mathrm{ppm}{ }^{241} \mathrm{Am}$} \\
\hline \multicolumn{4}{|l|}{ Uranium $^{a}$} \\
\hline${ }^{234} \mathrm{U}$ & \multirow{3}{*}{\multicolumn{3}{|c|}{$\begin{array}{r}0.0055 \\
0.7200 \\
99.2745\end{array}$}} \\
\hline${ }^{235} \mathrm{U}$ & & & \\
\hline${ }^{238} \mathrm{U}$ & & & \\
\hline \multirow{5}{*}{$\begin{array}{l}\text { Plutonium } \\
\qquad \begin{array}{l}{ }^{239} \mathrm{Pu} \\
{ }^{240} \mathrm{Pu} \\
{ }^{241} \mathrm{Pu} \\
{ }^{242} \mathrm{Pu}\end{array}\end{array}$} & Initial & Revised & Decay time, $d$ \\
\hline & 80.6 & 80.7 & $-^{d}$ \\
\hline & 13.4 & $-^{c}$ & $-^{d}$ \\
\hline & 5.2 & 4.8 & $605^{e}$ \\
\hline & 0.8 & $-c$ & $-^{d}$ \\
\hline \multicolumn{4}{|l|}{ Other } \\
\hline${ }^{241} \mathrm{Am}^{f}$ & \multicolumn{3}{|l|}{5000} \\
\hline
\end{tabular}

${ }^{\circ}$ Taken from ref. 14.

${ }^{b}$ Initial from ref. 5; revised from ref. 9.

No revised measurement reported.

Decay time not calculated.

${ }^{e}$ Calculated decay time required to change ${ }^{241} \mathrm{Pu}$ from the initial to the revised composition.

In ppm (wt) of Pu, from ref. 9.

Table 4. Fractional composition of $\mathrm{UO}_{2}$ and $\mathrm{PuO}_{2}$ in the $\mathrm{MOX}$ fuel

\begin{tabular}{|c|c|c|c|c|c|}
\hline \multirow[b]{2}{*}{ Case } & \multirow{2}{*}{$\begin{array}{l}\text { Pin } \\
\text { ID }\end{array}$} & \multirow{2}{*}{$\begin{array}{c}\text { No. of same } \\
\text { type pins }\end{array}$} & \multirow{2}{*}{$\begin{array}{c}\mathrm{Wt} \% \\
\text { fissile } \mathrm{Pu} \\
\end{array}$} & \multicolumn{2}{|c|}{ Weight fraction in $\mathrm{MOX}\left(\mathrm{UO}_{2}+\mathrm{PuO}_{2}\right)$} \\
\hline & & & & of $\mathrm{UO}_{2}$ & of $\mathrm{PuO}_{2}$ \\
\hline 1 & 067 & 24 & 3.31 & 0.961423 & 0.038577 \\
\hline 2 & 141 & 64 & 2.84 & 0.966901 & 0.033099 \\
\hline 3 & 079 & 92 & 3.10 & 0.963870 & 0.036130 \\
\hline $4,5,6$ & 167 & 64 & 2.84 & 0.966901 & 0.033099 \\
\hline
\end{tabular}

${ }^{a}$ Computed from data in Tables 2 and 3 and atomic weights of ref. 14 . 
TO CENTER OF CORE (CYCLE 2)

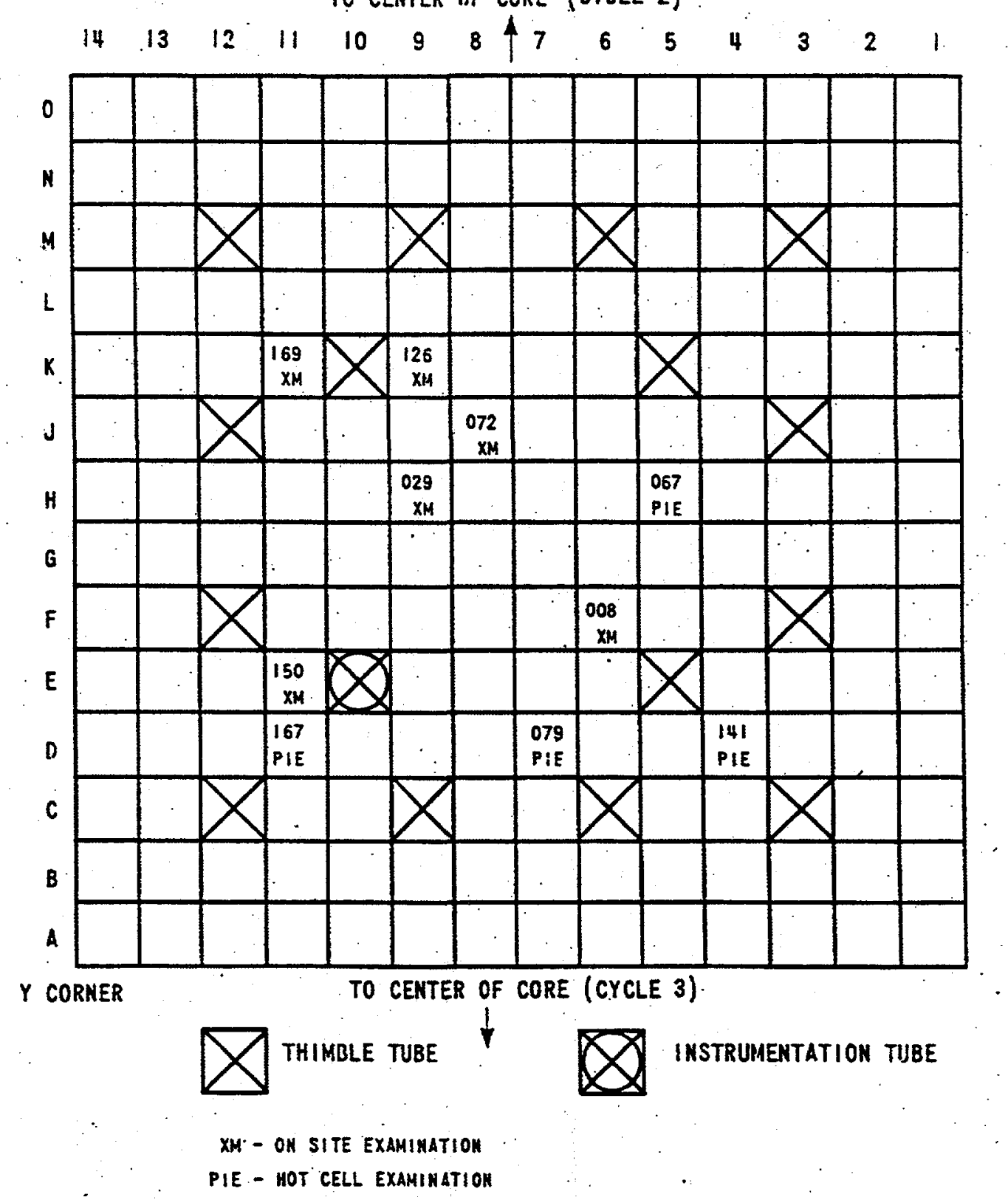

Fig. 1. Location of rods removed from San Onofre Plutonium Demonstration Assembly D51X for post-irradiation examination. Source: ref. 11. 


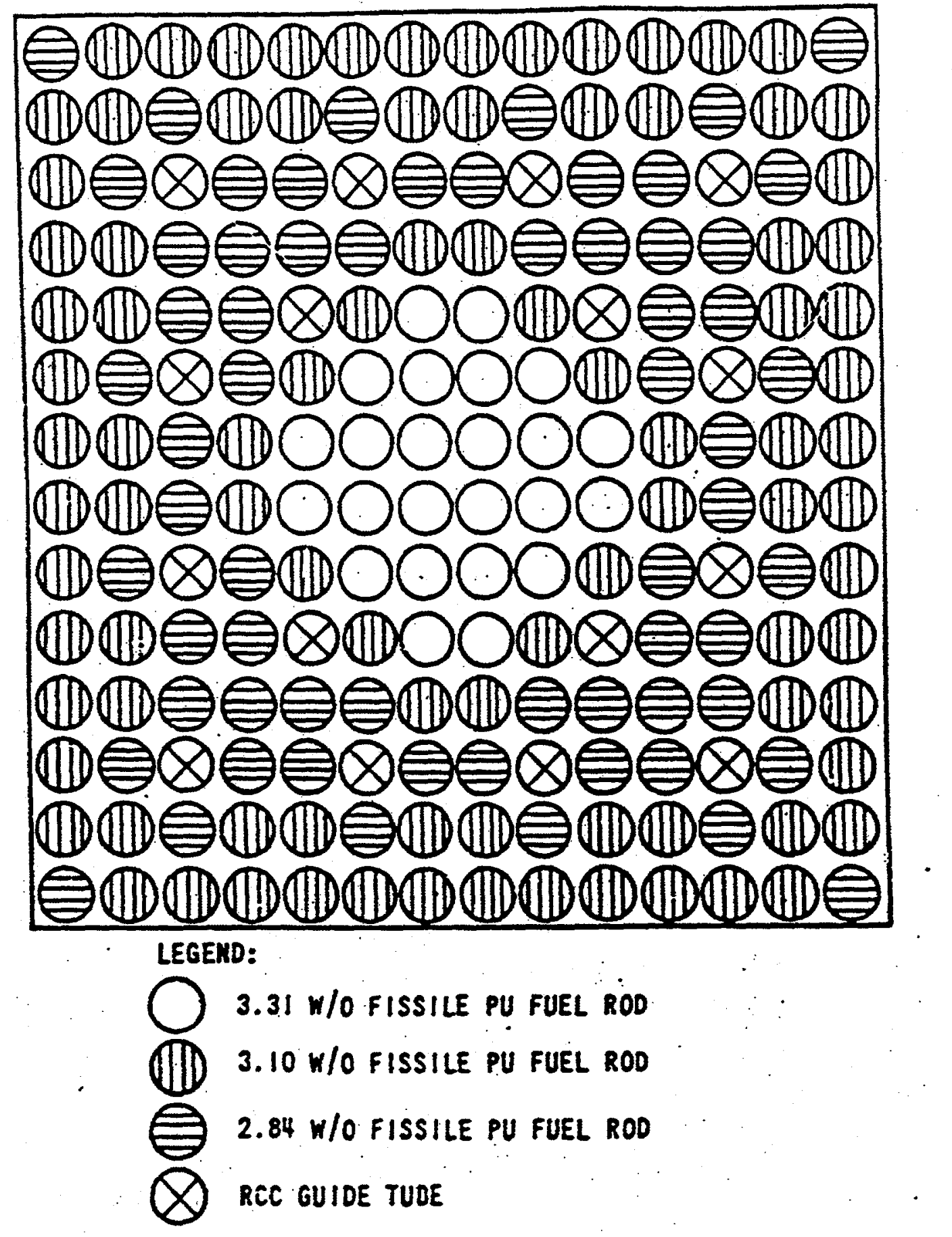

Fig. 2. Enrichment pattern for the four plutonium assemblies. Source: refs. 6 and 9. 


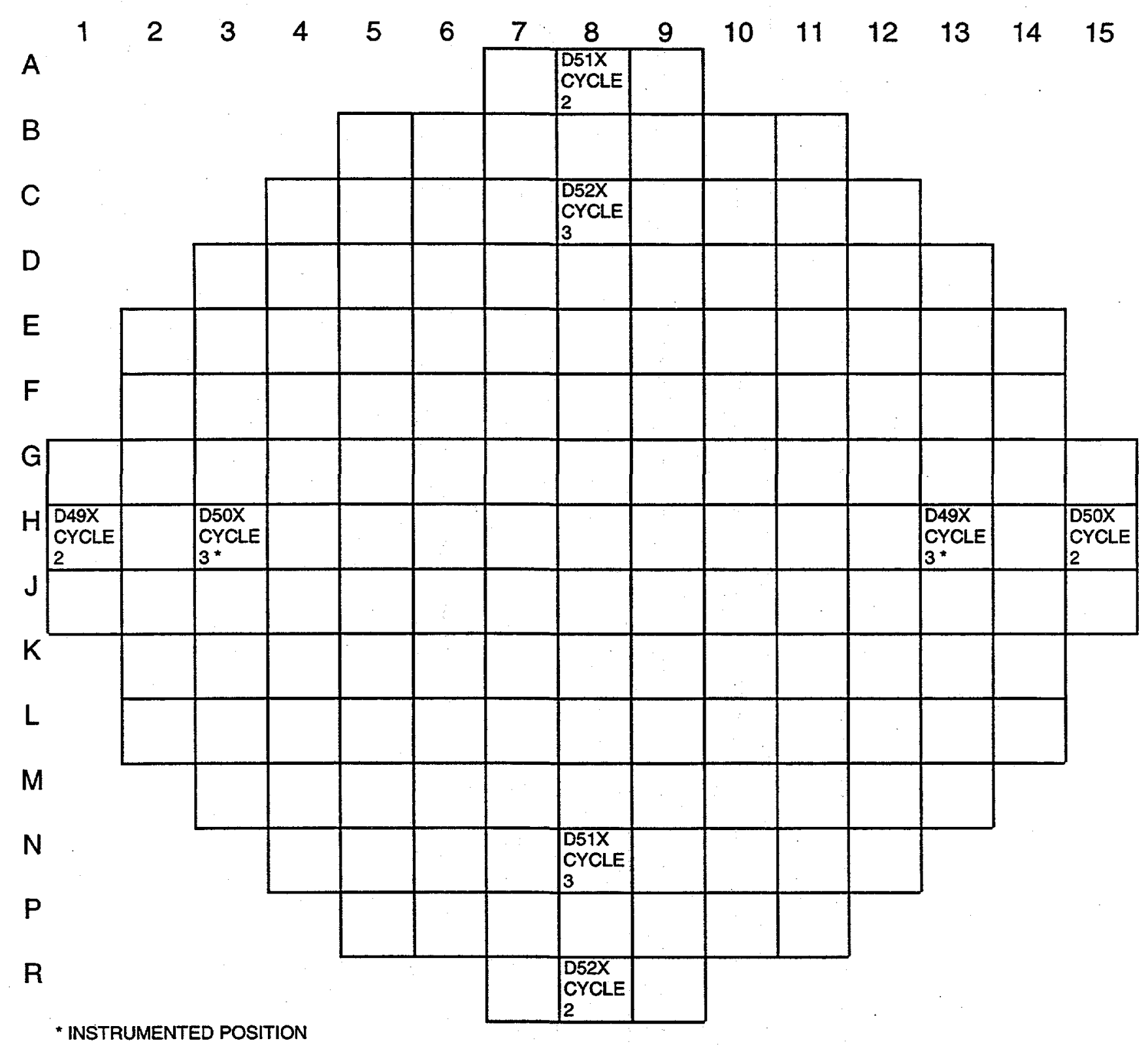

Fig. 3. Location of plutonium demonstration assemblies in San Onofre cycle 2 and cycle 3. Source: refs. 10 and 11. 


\section{THE PWR OPERATIONS DATA AND MODEL OF ASSEMBLIES}

The San Onofre PWR, Unit I, operations data, pertaining to the MOX fuel assemblies in cycles 2 and 3 are presented in Table 5 . The pellet sample burnups were derived from the ${ }^{148} \mathrm{Nd}$ measurements, as described in the appendix. The average cycle power experienced by each of the six pellet samples were calculated from the burnup and cycle times.

Portions of the operating conditions were listed in Table 2. The clad and water moderator temperatures ${ }^{5}$ are in the "assembly general data" listed in the table. The moderator density was obtained by interpolation of data in the temperature-pressure-density table ${ }^{13}$ at $578^{\circ} \mathrm{F}$ and 2100 psia. $^{6}$

The effective fuel temperatures, applied in the resonance treatment, were obtained from the fuel-temperature-vs-rod linear power curve ${ }^{2}$ in Fig. 4. The curve was developed for the Obrigheim PWR. There are similarities in lattice $(14 \times 14)$, pellet OD $(<1 \%$ difference) and moderator temperature (differ by $4.5 \mathrm{~K}$ ) between the San Onofre and Obrigheim reactors. This method of estimating fuel temperature was applied in the validation of H. B. Robinson PWR analyses. ${ }^{2}$ The resulting temperatures are given in Table 5.

The unit cell zone geometry data for Path-B of SAS2H is listed in Table 6.

It is recommended that cross sections should be determined during the neutronics calculation for all nuclides that are significant to the results, as recommended in the most current validation study ${ }^{4}$ and a burnup-credit sensitivity study. ${ }^{15}$ 
Table 5. San Onofre operating data, including sample pellet powers and resonance-type fuel temperatures

\begin{tabular}{|c|c|c|c|c|}
\hline $\begin{array}{l}\text { Operation data type, Pin ID } \\
\text { (height, in.) }\end{array}$ & Units & Cycle 2 & Cycle 3 & $\begin{array}{l}\text { Total } \\
\text { burnup }\end{array}$ \\
\hline \multicolumn{5}{|l|}{ Cycle times $^{a}$} \\
\hline Startup date & & $11 / 18 / 70$ & $3 / 1 / 72$ & \\
\hline Shutdown date & & $12 / 26 / 71$ & $6 / 2 / 73$ & \\
\hline Uptime & Days & 403 & 459 & \\
\hline Downtime & Days & 66 & $--^{b}$ & \\
\hline Fuel pellet burnups ${ }^{c}$ & MWd/MTHM & & & \\
\hline $067(53.0)$ & & 8,167 & - & 8,167 \\
\hline $141(95.5)$ & & 6,808 & - & 6,808 \\
\hline $079(49.0)$ & & 7,015 & 13,877 & 20,891 \\
\hline $167(16.5)$ & & 5,999 & 11,448 & 17,447 \\
\hline $167(95.5)$ & & 6,434 & 12,279 & 18,713 \\
\hline $167(114.0)$ & & 3,843 & 7,222 & 11,065 \\
\hline Fuel pellet powers ${ }^{d}$ & MW/MTHM & & & \\
\hline $067(53.0)$ & & 20.266 & - & \\
\hline 141 (95.5) & & 16.894 & - & \\
\hline $079(49.0)$ & & 17.406 & 30.232 & \\
\hline $167(16.5)$ & & 14.885 & 24.942 & \\
\hline 167 (95.5) & & 15.965 & 26.751 & \\
\hline $167(114.0)$ & & 9.536 & 15.735 & \\
\hline Effective fuel temperatures ${ }^{e}$ & $\mathrm{~K}$ & & & \\
\hline $067(53.0)$ & & 744 & - & \\
\hline $141(95.5)$ & & 713 & - & \\
\hline $079(49.0)$ & & 718 & 839 & \\
\hline $167(16.5)$ & & 695 & 787 & \\
\hline $167(95.5)$ & & 705 & 805 & \\
\hline $167(114.0)$ & & 650 & 703 & \\
\hline Shutdown to analysis times $b$ & Days & & & \\
\hline $067 \quad(53.0)$ & & 717 & - & \\
\hline $141(95.5)$ & & 719 & - & \\
\hline $079(49.0)$ & & & 194 & \\
\hline $167(16.5)$ & & & 187 & \\
\hline $167(95.5)$ & & & 187 & \\
\hline $167(114.0)$ & & & 192 & \\
\hline
\end{tabular}

${ }^{a}$ Data taken from refs. 10 and 11 .

${ }^{b}$ Time from cycle shutdown to sample analysis.

Determined in the appendix from ${ }^{148} \mathrm{Nd}$ measurements.

${ }^{d}$ Calculated directly from the burnup- and cycle-time data.

${ }^{\mathrm{E} E f f e c t i v e ~ f u e l ~ t e m p e r a t u r e ~ f o r ~ r e s o n a n c e ~ t r e a t m e n t . ~}$ 


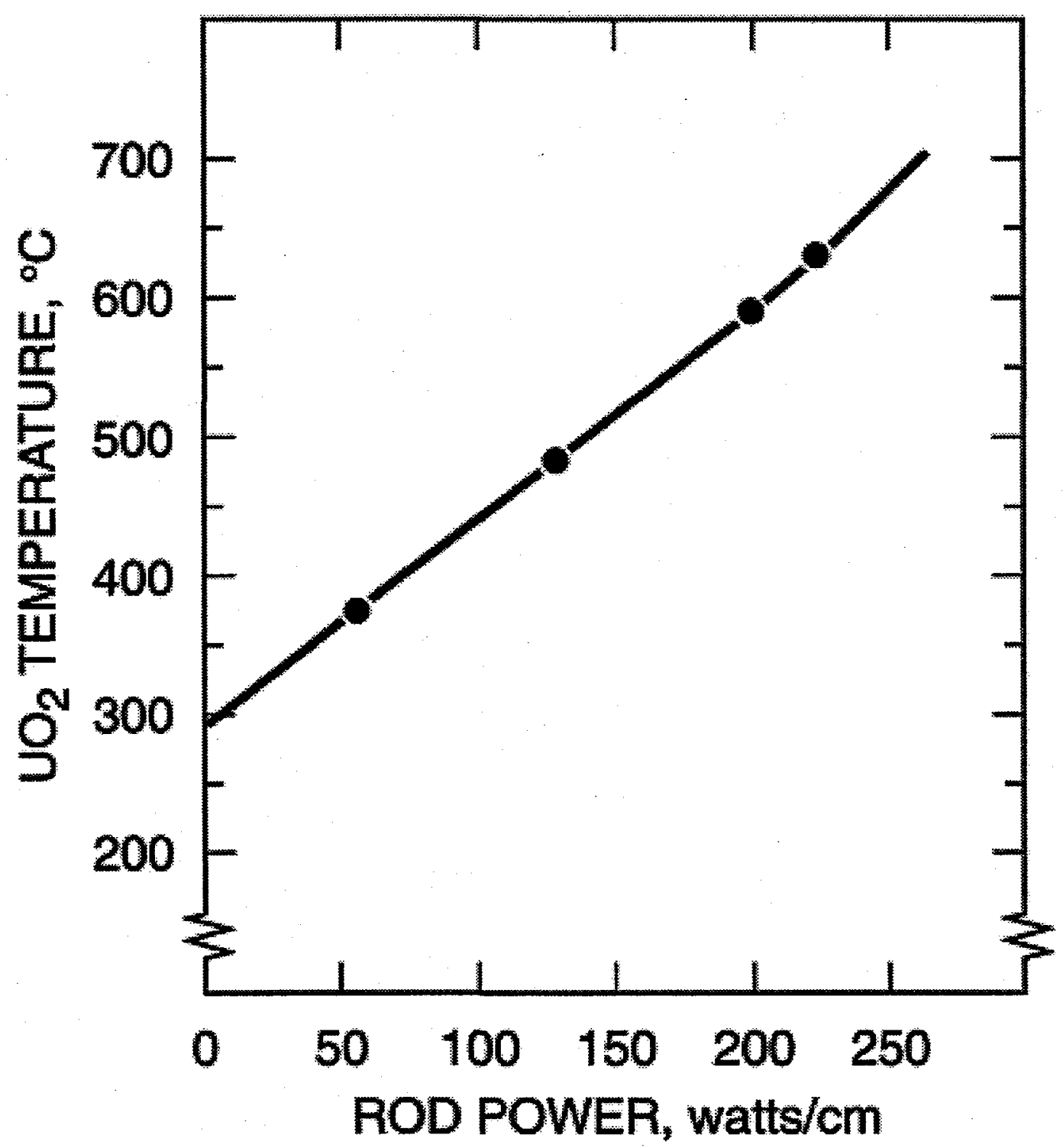

Fig. 4. Fuel-temperature-vs-rod power for Obrigheim. Source: ref. 2. 
Table 6. Effective SAS2H geometry of the San Onofre MOX assembly model

\begin{tabular}{|c|c|c|c|c|}
\hline Cycle & $\begin{array}{c}\text { Radial } \\
\text { zone }\end{array}$ & Mixture No. & Composition & $\begin{array}{l}\text { Effective radius } \\
(\mathrm{cm})\end{array}$ \\
\hline 2 & 1 & 3 & Borated moderator & 0.64897 \\
\hline 2 & 2 & 5 & Stainless steel-304 & 0.67945 \\
\hline 2 & 3 & 3 & Borated moderator ${ }^{a}$ & 0.79677 \\
\hline 2 & 4 & 500 & $\begin{array}{l}\text { Homogenized fuel, clad and borated } \\
\text { moderator }\end{array}$ & 2.78870 \\
\hline 2 & 5 & 3 & $\begin{array}{l}\text { Borated moderator between } \\
\text { assemblies }^{b}\end{array}$ & 2.81266 \\
\hline 3 & 1 & 3 & Borated moderator & 0.64897 \\
\hline 3 & 2 & 5 & Stainless steel-304 & 0.67945 \\
\hline 3 & 3 & 3 & Borated moderator $^{a}$ & 0.84510 \\
\hline 3 & 4 & 500 & $\begin{array}{l}\text { Homogenized fuel, clad and borated } \\
\text { moderator }\end{array}$ & 2.78870 \\
\hline 3 & 5 & 3 & $\begin{array}{l}\text { Borated moderator between } \\
\text { assemblies }^{b}\end{array}$ & 2.81266 \\
\hline
\end{tabular}

${ }^{a}$ Radius different in cycles 2 and 3 to account for the removal of the two pins indicated in Tables 1 and 4.

${ }^{b}$ Calculated from assembly pitch and equivalent core diameter in Table 2. 


\section{ISOTOPIC MEASUREMENTS FOR MOX FUEL SAMPLES}

Samples from the San Onofre MOX spent fuel were prepared at the Battelle Memorial Institute hot-cell facility (Columbus, Ohio). These samples were sent to the Westinghouse Waltz Mill Analytical Laboratory for the comprehensive spectrometric analysis of isotopic concentrations. The measured isotopic compositions, as atom ratios, of the six MOX sample pellets are given in Table 7. These results pertain to the listed date of analysis. The results for the uranium and plutonium isotopes adjusted to the end of the irradiation time of the sample are presented in Table 8 .

The first 11 isotopic ratios (through ${ }^{148} \mathrm{Nd} /{ }^{238} \mathrm{U}$ ) that are listed in Table 7 were performed by mass spectrometric methods. The remaining five ratios in the table were measured by alpha spectrometry. Although these five cases were analyzed later, they were decay corrected in ref. 12 to the dates given in the table for consistency.

Table 7. Measured isotopic compositions of San Onofre MOX spent fuel in atom ratios at time of analysis

\begin{tabular}{|c|c|c|c|c|c|c|}
\hline Pin ID (height, in.) & $067(53.0)$ & $141(95.5)$ & $079(49.0)$ & $167(16.5)$ & $167(95.5)$ & $167(114.0)$ \\
\hline Date of analysis & $12 / 11 / 73$ & $12 / 13 / 73$ & $12 / 13 / 73$ & $12 / 06 / 73$ & $12 / 06 / 73$ & $12 / 11 / 73$ \\
\hline Days after shutdown & 717 & 719 & 194 & 187 & 187 & 192 \\
\hline $\begin{array}{l}\text { Burnup, } \\
\text { MWd,MTHM }\end{array}$ & 8,167 & 6,808 & 20,891 & 17,447 & 18,713 & 11,065 \\
\hline${ }^{234} \mathrm{U} / \mathrm{U} \times 10^{-2}$ & 0.005 & 0.006 & 0.005 & 0.005 & 0.005 & 0.005 \\
\hline${ }^{235} \mathrm{U} / \mathrm{U} \times 10^{-2}$ & 0.628 & 0.641 & 0.470 & 0.483 & 0.479 & 0.569 \\
\hline${ }^{236} \mathrm{U} / \mathrm{U} \times 10^{-2}$ & 0.023 & 0.018 & 0.052 & 0.050 & 0.051 & 0.032 \\
\hline${ }^{238} \mathrm{U} / \mathrm{U} \times 10^{-2}$ & 99.344 & 99.335 & 99.473 & 99.462 & 99.465 & 99.394 \\
\hline${ }^{238} \mathrm{Pu} / \mathrm{Pu} \times 10^{-2}$ & 0.557 & 0.462 & 0.989 & 0.860 & 0.884 & 0.642 \\
\hline${ }^{239} \mathrm{Pu} / \mathrm{Pu} \times 10^{-2}$ & 71.886 & 73.218 & 56.998 & 57.626 & 57.130 & 66.193 \\
\hline${ }^{240} \mathrm{Pu} / \mathrm{Pu} \times 10^{-2}$ & 19.050 & 18.812 & 26.422 & 26.613 & 26.593 & 22.401 \\
\hline${ }^{241} \mathrm{Pu} / \mathrm{Pu} \times 10^{-2}$ & 7.210 & 6.384 & 12.530 & 12.047 & 12.444 & 9.088 \\
\hline${ }^{242} \mathrm{Pu} / \mathrm{Pu} \times 10^{-2}$ & 1.295 & 1.124 & 3.061 & 2.854 & 2.949 & 1.678 \\
\hline${ }^{239} \mathrm{Pu} /{ }^{238} \mathrm{U} \times 10^{-2}$ & 2.619 & 2.293 & 1.741 & 1.594 & 1.601 & 1.965 \\
\hline${ }^{148} \mathrm{Nd} /{ }^{238} \mathrm{U} \times 10^{-4}$ & 1.508 & 1.250 & 3.875 & 3.226 & 3.460 & 2.046 \\
\hline${ }^{241} \mathrm{Am} /{ }^{239} \mathrm{Pu} \times 10^{-2}$ & $-a$ & $-{ }^{a}$ & $-a$ & 6.51 & 6.83 & 1.59 \\
\hline${ }^{243} \mathrm{Am} /{ }^{239} \mathrm{Pu} \times 10^{-2}$ & $-^{a}$ & $-{ }^{a}$ & $-{ }^{a}$ & 1.41 & 1.55 & 0.27 \\
\hline${ }^{236} \mathrm{Pu} /{ }^{239} \mathrm{Pu} \times 10^{-9}$ & 4.04 & 4.60 & 17.7 & 12.4 & 13.4 & 6.50 \\
\hline${ }^{238} \mathrm{Pu} /{ }^{239} \mathrm{Pu} \times 10^{-3}$ & 7.65 & 6.16 & 17.0 & 14.7 & 15.2 & 9.43 \\
\hline${ }^{237} \mathrm{~Np} / \mathrm{U} \times 10^{-5 b}$ & $-a$ & $-^{a}$ & $-a$ & 9.7 & 11.1 & 5.7 \\
\hline
\end{tabular}

${ }^{a}$ No measurement.

${ }^{b}$ In place of atom ratio, units are grams ${ }^{237} \mathrm{~Np} / \mathrm{g} \mathrm{U}$.

Source: ref. 12. 
Although there were no indications that uncertainties or standard deviations were developed for the measured data, the reanalysis of three samples "showed excellent agreement between initial and repeat results."

Table 8. Measured isotopic compositions of San Onofre MOX spent fuel in atom ratios adjusted to shutdown time

\begin{tabular}{lrrrrrr}
\hline Pin ID (height, in.) & $067(53.0)$ & $141(95.5)$ & $079(49.0)$ & $167(16.5)$ & $167(95.5)$ & $167(114.0)$ \\
\hline Burnup, & & & & & & \\
MWd/MTHM & 8,167 & 6,808 & 20,891 & 17,447 & 18,713 & 11,065 \\
${ }^{234} \mathrm{U} / \mathrm{U} \times 10^{-2}$ & 0.005 & 0.006 & 0.005 & 0.005 & 0.005 & 0.005 \\
${ }^{235} \mathrm{U} / \mathrm{U} \times 10^{-2}$ & 0.628 & 0.641 & 0.470 & 0.483 & 0.479 & 0.569 \\
${ }^{236} \mathrm{U} / \mathrm{U} \times 10^{-2}$ & 0.023 & 0.018 & 0.052 & 0.050 & 0.051 & 0.032 \\
${ }^{238} \mathrm{U} / \mathrm{U} \times 10^{-2}$ & 99.344 & 99.335 & 99.473 & 99.462 & 99.465 & 99.394 \\
${ }^{238} \mathrm{Pu} / \mathrm{Pu} \times 10^{-2}$ & 0.560 & 0.465 & 0.986 & 0.857 & 0.880 & 0.639 \\
${ }^{239} \mathrm{Pu} / \mathrm{Pu} \times 10^{-2}$ & 71.345 & 72.729 & 56.744 & 57.379 & 56.877 & 65.979 \\
${ }^{240} \mathrm{Pu} / \mathrm{Pu} \times 10^{-2}$ & 18.907 & 18.686 & 26.304 & 26.499 & 26.495 & 22.328 \\
${ }^{241} \mathrm{Pu} / \mathrm{Pu} \times 10^{-2}$ & 7.903 & 7.003 & 12.919 & 12.423 & 12.831 & 9.382 \\
${ }^{242} \mathrm{Pu} / \mathrm{Pu} \times 10^{-2}$ & 1.285 & 1.116 & 3.047 & 2.842 & 2.936 & 1.673 \\
${ }^{239} \mathrm{Pu} /{ }^{238} \mathrm{U} \times 10^{-2}$ & 2.619 & 2.293 & 1.741 & 1.594 & 1.601 & 1.965 \\
\hline
\end{tabular}

Source: ref. 12 . 


\section{SUMMARY}

One of the important functions of the Fissile Materials Disposition Program is to calculate the isotopic composition of mixed-oxide fuel withdrawn from reactors. The validation of depletion codes for this purpose have been conducted ${ }^{2-4}$ for uranium-only fueled light-water reactors.

During the period from 1968 to 1974 the EEI-Westinghouse Plutonium Recycle Demonstration Program was established to examine the use of MOX fuel. One of the reactors used in the program was the San Onofre PWR Unit I. Many reports of the preliminary plans, progress and summaries were written during the program. The main purpose of this report is to compile the assembly design and cycle operating data of the MOX fuel assemblies into a single report. It is intended that the latest and required data for most depletion codes is included in this compilation. One of the codes in which the data may be applied is the SAS2 $\mathrm{H}^{13}$ control module of the SCALE system. Also, data which may be required for lattice codes are included (Figs. 1, 2 and 3). The results of both mass and alpha spectrometer analyses, producing 16 atom ratios of significant isotopes, are presented in Table 7.

An effort was made to have the correct reference given for each item of data. When the item was calculated from other data, a reference was given to the proper tables. In a few cases, where data were lacking, the method of estimation was explained. The burnup data reported, ${ }^{12}$ having been calculated in 1974, was not considered accurate. A more universally applied method, as covered in the appendix, was used for converting ${ }^{148} \mathrm{Nd}$ data to burnup.

It was concluded that the comprehensive design and operating data and the isotopic MOX spent fuel measurements for the San Onofre PWR were of adequate quality for the proper validation of depletion codes. Calculations that were performed with SAS2H for the six samples using the data of this report indicated that the data were adequate. 


\section{REFERENCES}

1. R. T. Primm III, B. D. Murphy, J. C. Ryman, and O. W. Hermann, Reference Spent Fuel Characteristics for Plutonium Disposition Reactors, Rev. 1, ORNLMD/LTR-17, Oak Ridge Natl. Lab., April 1995.

2. O. W. Hermann, S. M. Bowman, M. C. Brady, and C. V. Parks, Validation of the SCALE System for PWR Spent Fuel Isotopic Composition Analyses, ORNLTM-12667, Martin Marietta Energy Systems, Inc., Oak Ridge Natl. Lab., 1995

3. M. D. DeHart and O. W. Hermann, An Extension of the Validation of SCALE (SAS2H) Isotopic Predictions for PWR Spent Fuel, ORNLTM-13317, Lockheed Martin Energy Research Corp., Oak Ridge Natl. Lab., September 1996.

4. O. W. Hermann and M. D. DeHart, Validation of SCALE (SAS2H) Isotopic Predictions for BWR Spent Fuel, ORNL/TM-13315, Lockheed Martin Energy Research Corp., Oak Ridge Natl. Lab., 1998.

5. B. F. Momsen, An Analysis of Plutonium Recycle Fuel Elements in San Onofre - I. Master's thesis, Massachusetts Institute of Technology, May 1974.

6. Southern California Edison Co., San Onofre Nuclear Generation Station, Unit 1, Operating History and Verification of Design Objectives, Part 1, Vol. 1, Docket-50206-79.

7. W. D. Leggett III, In-Core Instrumentation for the San Onofre Nuclear Generation Station, WCAP-3269-46, Westinghouse Electric Corp., March 1965.

8. J. Haley, EEI - Westinghouse Plutonium Recycle Demonstration Program Progress Report for the Period Ending April, 1970, WCAP-4167-1, Westinghouse Electric Corp., May 1970.

9. J. Haley, EEI - Westinghouse Plutonium Recycle Demonstration Program Progress Report for the Period Ending December, 1970, WCAP-4167-2, Westinghouse Electric Corp., March 1971.

10. J. B. Melehan, EEI - Westinghouse Plutonium Recycle Demonstration Program Progress Report for the Period October 1971 - March 1972, WCAP-4167-4, Westinghouse Electric Corp., December 1972.

11. T. W. Wallace; EEI - Westinghouse Plutonium Recycle Demonstration Program Progress Report for the Period April 1973 - September 1973, WCAP-4167-6, Westinghouse Electric Corp., December 1973. 
12. T. W. Wallace, EEI - Westinghouse Plutonium Recycle Demonstration Program Progress Report, October 1973-October 1974, WCAP-4167-7, Westinghouse Electric Corp., February 1975.

13. O. W. Hermann and C. V. Parks, "SAS2H: A Coupled One-Dimensional Depletion and Shielding Analysis Code," Sect. S2 of SCALE: A Modular Code System for Performing Standardized Computer Analyses for Licensing Evaluation, NUREG/CR-0200, Rev. 5 (ORNL/NUREG/CSD-2/R5), Vols. I, II, and III (March 1997). Available from Radiation Safety Information Computational Center at Oak Ridge National Laboratory as CCC-545.

14. J. R. Parrington, H. D. Knox, S. L. Breneman, E. M. Baum, and F. Feiner (made revisions), Chart of the Nuclides, $15^{\text {th }}$ Edition, General Electric Co. and KAPL, Inc., 1996.

15. M. D. DeHart, Sensitivity and Parametric Evaluations of Significant Aspects of Burnup Credit for PWR Spent Fuel Packages, ORNL/TM-12973, Lockheed Martin Energy Research Corp., Oak Ridge Natl. Lab., 1996.

16. S. D. Atkin, Destructive Examination of 3-Cycle LWR Fuel Rods from Turkey Point Unit 3 for the CLIMAX-Spent Fuel Test, HEDL-TME 80-89, Hanford Engineering Development Laboratory, 1981. 


\section{APPENDIX A}

\section{SAMPLE BURNUP DETERMINATIONS}

This appendix provides an expanded explanation regarding the sample burnup data listed in Table 5. First, the reasons are given why the available burnup data ${ }^{\mathrm{A} .1}$ are considered inadequate, probably due to the use of methods that have become obsolete. Then, the method applied for converting the ${ }^{148} \mathrm{Nd}$ measurement to burnup is referenced and discussed. Finally, the total burnup results and the separate cycle data are shown.

There is a high degree of confidence in the ANSU/ASTM standards for converting ${ }^{148} \mathrm{Nd}$ measurements to burnup in nuclear research concerning uranium-only fueled LWRs. A total of 68 spent fuel samples from eight different reactors have been used in comparisons of measured and calculated isotopic results in previous validation studies. ${ }^{\text {A.2-A.4 }}$ The referenced burnups were, except for one reactor, derived from the ${ }^{148} \mathrm{Nd}$ analysis. In 40 of the sample cases, from five reactors, the ${ }^{148} \mathrm{Nd}$ measured result was given and compared with the SAS2H calculation that applied the ${ }^{148} \mathrm{Nd}$ derived burnup. The computed/measured ${ }^{148} \mathrm{Nd}$ differences in the 40 cases ranged form -2.4 to $1.7 \%$, with an average of $-0.32 \%$. The averages for the five reactors were $-1.4,1.7,0.4,-2.0$ and $0.3 \%$, with an average of $0.20 \%$. Or, the average of the absolute values of the reactor averages was $1.16 \%$.

The preceding comparisons of analyses and SAS2H results validate that the methods of converting ${ }^{148} \mathrm{Nd}$ measurements to burnups are adequate. However, preliminary computations, using SAS2H, for the MOX fuel cases gave ${ }^{148} \mathrm{Nd}$ differences as large as $4 \%$ for 1 -cycle cases and $12 \%$ for 2 -cycle cases. Although the reports giving data that were used in the validation study did not usually give the conversion factors used in determining burnup, the data ${ }^{A .5}$ for the Turkey Point PWR did contain the required conversion factors. Thus, the decision was made to apply the conversion factors used with the Turkey Point data in deriving burnups for the MOX fuel for the following reasons. First, applying these factors showed that the referenced burnups ${ }^{\text {A.1. }}$ were too high by approximately the same differences indicated by the ${ }^{148} \mathrm{Nd}$ code-to-measured-results comparisons. Using the same factors from the Turkey Point PWR on data for the Calvert Cliffs PWR, the Cooper BWR and the JPDR BWR of 18 cases gave values within about $1 \%$ of the reported burnups. The discussion on the Turkey Point PWR referred to the ANSI/ASTM Standards E321-75 and E267, and that on the Calvert Cliffs PWR and Cooper BWR referred to the ANSI/ASTM Standard E321-79 and E219.

One more question should be considered before using the above ${ }^{148} \mathrm{Nd}$-burnup conversion method (i.e., factors applied in Turkey Point PWR cases) for MOX spent fuel. Higher concentrations of $\mathrm{Pu}$ isotopes and lower concentrations of $\mathrm{U}$ isotopes are noted in the average MOX fuel than in the average uranium-only fuel during irradiation. There are two factors that this can change: the average fission fraction of ${ }^{148} \mathrm{Nd}$ production, and the average recoverable energy per fission. The percent fission fractions (based on thermal reactors) for ${ }^{148} \mathrm{Nd}$ (or mass 148) listed in ENDF/B-V V.6 are 1.670 for ${ }^{235} \mathrm{U}, 2.081$ for ${ }^{238} \mathrm{U}$ (fast), 1.635 for ${ }^{239} \mathrm{Pu}$, and 1.990 for ${ }^{241} \mathrm{Pu}$. An approximate average fission fraction for a given case may be calculated by weighting these four fission fractions by the average isotopic density times the average microscopic fission cross section 
of the corresponding isotope (or, rather, the isotopic average macroscopic fission cross section). In two SAS2H trial cases, average macroscopic fission cross sections of the isotopes were estimated from atomic densities and cross sections listed in the case outputs. An estimate of the sum of the weighted fission fractions indicated a 1 to $2.5 \%$ increase in the average fission fraction from MOX fuel compared with that from typical uranium-only fuel. The ORIGEN-S code computes and writes the total recoverable energy per fission for each time step. The values of the average energy per fission of MOX fueled reactors compared with uranium-only reactors indicate an increase of approximately 1 to $1.5 \%$. The fission fraction is in the denominator, and the energy per fission is in the numerator in converting the ${ }^{148} \mathrm{Nd} / \mathrm{U}$ atom ratio to burnup. Thus, it is estimated that the burnup could be no greater than $1.5 \%$ less for MOX fuel than that produced by the conversion method used for uranium-only fuel cases.

The detailed procedure for converting the measured atom ratio of ${ }^{148} \mathrm{Nd} /{ }^{238} \mathrm{U}$ to burnup by using the same conversion factors, $\mathrm{C}$ and $\mathrm{F}_{148}$, applied in deriving the Turkey Point data, ${ }^{\text {A.S }}$ is the following:

$$
B=\operatorname{RCAF}_{\mathrm{u}}\left(1-\mathrm{D}_{238}\right) / \mathrm{F}_{148} \text {, }
$$

where

$$
\begin{aligned}
& \mathrm{B} \quad=\text { calculated burnup, } \mathrm{MWd} / \mathrm{MTHM}, \\
& \mathrm{R} \quad=\text { atom ratio of (final }{ }^{148} \mathrm{Nd} \text { atoms)/(final }{ }^{238} \mathrm{U} \text { atoms), } \\
& \mathrm{F}_{148} \quad=\text { fission fraction for mass } 148=0.0168,{ }^{\mathrm{A} .5} \\
& \mathrm{C} \quad=9600(\mathrm{MWd} / \mathrm{MTHM}) / \text { at. } \% \text { of fuel which fissions, }{ }^{\mathrm{A} .5} \\
& \mathrm{~A} \quad={ }^{238} \mathrm{U} \text { at. } \% \text { in natural } \mathrm{U}, \text { or } 99.2745, \\
& \mathrm{~F}_{\mathrm{v}} \quad={ } \text { weight fraction of } \mathrm{UO}_{2} \text { in the MOX from Table } 4, \\
& \mathrm{D}_{238} \quad={ }^{238} \mathrm{U} \text { fractional depletion, } 0.007 \text { per cycle estimated. }
\end{aligned}
$$

$F_{u}$ should be the atom fraction of $U$ in the $U+P u$ of the MOX, because each term of the equation is always the ratio of atoms. For the sample compositions, the atom ratio of $\mathrm{U}$ to $\mathrm{U}+\mathrm{Pu}$ is not significantly different than the weight ratio of $\mathrm{UO}_{2}$ to $\mathrm{UO}_{2}+\mathrm{PuO}_{2}$. The estimate of $\mathrm{D}_{238}$ is $0.007 \pm 0.002$, which should cause an error in $\mathrm{B}$ no greater than $0.2 \%$. The method in ref. A.5 applied the same factors $C$ and $F_{148}$ in converting $R$ to $B$, but equivalent measurements were used instead of $\mathrm{AF}_{\mathrm{u}}\left(1-\mathrm{D}_{238}\right)$.

As an example of using Eq. (A.1), consider the 2-cycle case for pin ID 079, where the value of $F_{u}$ from Table 4 is 0.963870 and $R=3.875 \times 10^{-4}$ :

$$
\begin{aligned}
\mathrm{B} & =3.875 \times 10^{-4} \times 9600 \times 99.2745 \times 0.96387 \times 0.986 / 0.0168 \\
& =20,891.4 \mathrm{MWd} / \mathrm{MTHM} .
\end{aligned}
$$


The reported burnup of $23,500 \mathrm{MWd} / \mathrm{MTHM}$ is $12.5 \%$ greater than that determined in Eq. (A.2). Burnups of the six cases computed by Eq. (A.1) are listed in Table A.1. The revised values are given in Table 5. It is seen that the old, or reported, burnups ${ }^{\text {A.1. }}$ are significantly greater than the revised burnups.

The calculation of the burnup for each cycle of the samples irradiated in both cycles 2 and 3 are given in Table A.2. The use of the reported ${ }^{\text {A.1 }}$ linear power for both cycles of the samples permitted the calculation of linear burnups, the fraction of total burnup per cycle, and the final burnup by cycle. These resulting burnups are listed in Table 5 , in addition to the computed cycle powers required in depletion code input.

Table A.1 Data applied in determining recommended burnup ${ }^{a}$

\begin{tabular}{ccccccccc}
\hline & & No. of & \multicolumn{3}{c}{ \% fissile } & \multicolumn{3}{c}{ B, MWd/MTHM } \\
\cline { 6 - 8 } Case & $\mathrm{R}$ & cycles & $1-\mathrm{D}_{238}$ & $\mathrm{Pu}$ & $\mathrm{F}_{\mathrm{u}}$ & revised & old & \% diff. \\
\hline 1 & $1.508 \times 10^{-4}$ & 1 & 0.993 & 3.31 & 0.961423 & 8,167 & 8,700 & 6.5 \\
2 & $1.250 \times 10^{-4}$ & 1 & 0.993 & 2.84 & 0.966901 & 6,808 & 7,200 & 5.8 \\
3 & $3.875 \times 10^{-4}$ & 2 & 0.986 & 3.10 & 0.963870 & 20,891 & 23,500 & 12.5 \\
4 & $3.226 \times 10^{-4}$ & 2 & 0.986 & 2.84 & 0.966901 & 17,447 & 19,800 & 13.5 \\
5 & $3.460 \times 10^{-4}$ & 2 & 0.986 & 2.84 & 0.966901 & 18,713 & 21,200 & 13.3 \\
6 & $2.046 \times 10^{-4}$ & 2 & 0.986 & 2.84 & 0.966901 & 11,065 & 12,500 & 13.0 \\
\hline
\end{tabular}

${ }^{a}$ Derived $\mathrm{B}$ by applying Eq. (A.1), the constants $\mathrm{F}_{148}, \mathrm{C}$ and $\mathrm{A}$, in addition to data in this table. ${ }^{b}\left(\mathrm{~B}_{\text {old }} / \mathrm{B}_{\text {revised }}-1\right) 100 \%$.

Table A.2 Calculation of burnup for each cycle for 2-cycle cases

\begin{tabular}{|c|c|c|c|c|c|c|c|c|c|c|}
\hline \multirow[b]{3}{*}{ Case } & \multirow{2}{*}{\multicolumn{2}{|c|}{$\frac{P_{\text {linear }}{ }^{a} \mathrm{kw} / \mathrm{ft}}{\text { Cycle }}$}} & \multicolumn{2}{|c|}{ Uptime, d } & \multicolumn{2}{|c|}{$\mathrm{B}_{\text {linear }}, \mathrm{kwd} / \mathrm{ft}$} & \multicolumn{2}{|c|}{ Fraction $B_{\text {lotal }}$} & \multicolumn{2}{|c|}{$\begin{array}{c}\mathrm{B}_{\text {cycle }} \\
\mathrm{MWd} / \mathrm{MTHM}\end{array}$} \\
\hline & & & \multicolumn{2}{|c|}{ Cycle } & \multicolumn{2}{|c|}{ Cycle } & \multicolumn{2}{|c|}{ Cycle } & \multicolumn{2}{|c|}{ Cycle } \\
\hline & 2 & 3 & 2 & 3 & 2 & 3 & 2 & 3 & 2 & 3 \\
\hline 3 & 3.8 & 6.6 & 403 & 459 & $1,531.4$ & $3,029.4$ & 0.335774 & 0.664226 & 7,015 & 13,877 \\
\hline 4 & 3.7 & 6.2 & 403 & 459 & $1,491.1$ & $2,845.8$ & 0.343817 & 0.656183 & 5,999 & 11,448 \\
\hline 5 & 3.7 & 6.2 & 403 & 459 & $1,491.1$ & $2,845.8$ & 0.343817 & 0.656183 & 6,434 & 12,279 \\
\hline 6 & 2.0 & 3.3 & 403 & 459 & 806.0 & $1,514.7$ & 0.347309 & 0.652691 & 3,843 & 7,222 \\
\hline
\end{tabular}

${ }^{a} \mathrm{P}_{\text {linear }}$ is linear power at the sample height in ref. A.1. 


\section{REFERENCES}

A.1. T. W. Wallace, EEI - Westinghouse Plutonium Recycle Demonstration Program Progress Report, October 1973 - October 1974, WCAP-4167-7, Westinghouse Electric Corp., February 1975.

A.2. O. W. Hermann, S. M. Bowman, M. C. Brady, and C. V. Parks, Validation of the SCALE System for PWR Spent Fuel Isotopic Composition Analyses, ORNLTM-12667, Martin Marietta Energy Systems, Inc., Oak Ridge Natl. Lab., 1995.

A.3. M. D. DeHart and O. W. Hermann, An Extension of the Validation of SCALE (SAS2H) Isotopic Predictions for PWR Spent Fuel, ORNLTM-13317, Lockheed Martin Energy Research Corp., Oak Ridge Natl. Lab., September 1996.

A.4. O. W. Hermann and M. D. DeHart, Validation of SCALE (SAS2H) Isotopic Predictions for BWR Spent Fuel, ORNL/TM-13315, Lockheed Martin Energy Research Corp., Oak Ridge Natl. Lab., 1998.

A.5. S. D. Atkin, Destructive Examination of 3-Cycle LWR Fuel Rods from Turkey Point Unit 3 for CLIMAX - Spent Fuel Test, HEDL-TME 80-89 Hanford Engineering Development Laboratory, 1981.

A.6. T. R. England, W. B. Wilson, R. E. Schenter, and F. M. Mann, Summary of ENDF/B-V Data for Fission Products and Actinides, NP-3787 (LA-UR 83-1285, ENDF-322), Los Alamos National Laboratory, 1984. 


\section{INTERNAL DISTRIBUTION}

1. B. B. Bevard

2. S. M. Bowman

3. B. L. Broadhead

4. J. J. Carbajo

5. E. D. Collins

6. B. S. Cowell

7. M. D. DeHart

8. F. C. Difilippo

9. M. B. Emmett

10. R. J. Ellis

11. M. B. Emmett

12. I. C. Gauld

13. J. C. Gehin

14. S. R. Greene

15-19. O. W. Hermann

20. T. W. Horning

21. D. T. Ingersoll
22. H. T. Kerr

23. M. A. Kuliasha

24. S. B. Ludwig

25. G. E. Michaels

26. B. D. Murphy

27. D. L. Moses

28-32. C. V. Parks

33. L. M. Petrie

34-38. R. T. Primm III

39. C. H. Shappert

40. J. C. Wagner

41. R. M. Westfall

42. Central Research Library

43-44. ORNL Laboratory Records (OSTI)

45. ORNL Laboratory Records-RC

\section{EXTERNAL DISTRIBUTION}

46. N. Abdurrahman, College of Engineering, Dept. of Mechanical Engineering, University of Texas, Austin, TX 78712

47. M. L. Adams, Department of Nuclear Engineering, Texas A\&M University, Zachry 129, College Station, TX 77843

48. H. Akkurt, College of Engineering, Dept. of Mechanical Engineering, University of Texas, Austin, TX 78712

49. D. Alberstein, Los Alamos National Laboratory, MS-E502, P.O. Box 1663, Los Alamos, NM 87545

50. J. Baker, Office of Fissile Materials Disposition, U.S. Department of Energy, MD-3, 1000 Independence Avenue SW, Washington, DC 20585

51. J. B. Briggs, Idaho National Environmental and Engineering Laboratory, P.O. Box 1625-3855, Idaho Falls, ID 83415-3855 
52. A. Caponiti, Office of Fissile Materials Disposition, U.S. Department of Energy, MD-3, 1000 Independence Avenue SW, Washington DC 20585

53-54. I. Carron, Department of Nuclear Engineering, Texas A\&M University, 129 Zachry, College Station, TX 77843-3133

55. K. Chidester, Los Alamos National Laboratory, MS-E502, P.O. Box 1663, Los Alamos, NM 87545

56. W. Danker, U.S. Department of Energy, MD-3, 1000 Independence Avenue SW, Washington DC 20585

57. T. W. Doering, Framatome Cogema Fuels, 1261 Town Center Drive, Las Vegas, NV 89134

58. T. Gould, Lawrence Livermore National Laboratory, P.O. Box 808, MS-L186, Livermore, CA 94551

59. L. Holgate, Office of Fissile Materials Disposition, U.S. Department of Energy, MD-1/2, 1000 Independence Avenue SW, Washington, DC 20585

60. L. Jardine, Lawrence Livermore National Laboratory, P.O. Box 808, MS-L166, Livermore, CA 94551

61. Dr. Alexander Kalashnikov, Institute of Physics and Power Engineering, 1 Bondarenko Square, Obninsk, Kaluga Region, Russia 249020

62-66. D. E. Klein, Associate Vice Chancellor for Special Engineering Programs, The University of Texas System, 210 West Sixth Street, Austin, TX 78701

67. J. O. Nulton, Office of Fissile Materials Disposition, U.S. Department of Energy, MD-3, 1000 Independence Avenue SW, Washington DC 20585

68. Dr. Stephen L. Passman, Sandia National Laboratories, Suite 110, 950 L'Enfant Plaza, SW, Washington DC 20024-2123

69-73. Dr. Alexander Pavlovitchev, Russian Research Center "Kurchatov Institute," Institute of Nuclear Reactors VVER Division, VVER Physics Department, 123182, Kurchatov Square, 1, Moscow, Russia

74. K. L. Peddicord, Associate Vice Chancellor, Texas A\&M University, 120 Zachry, College Station, TX 77843-3133

75. G. Radulescu, Framatome Cogema Fuels, 1261 Town Center Drive, MS-423, Las Vegas, NV 89143

76. W. D. Reece, Texas A\&M University, Department of Nuclear Engineering, Zachry 129, College Station, TX 77843-3133

77. P. T. Rhoads, Office of Fissile Materials Disposition, U.S. Department of Energy, MD-4, 1000 Independence Avenue SW, Washington, DC 20585

78. D. A. Thomas, Framatome Cogema, 1261 Town Center Drive, Las Vegas, NV 89134

79. J. Thompson, Office of Fissile Materials Disposition, U.S. Department of Energy, MD-4, 1000 Independence Avenue SW, Washington DC 20585 
80. Fitz Trumble, Westinghouse Savannah River Company, Building 730R, Room 3402, WSRC, Aiken, SC 29808 